\title{
Erratum to: Andrei Shleifer: The failure of judges and the rise of regulators
}

Cambridge: MIT Press, 2012, viii + 343 pages. USD 40.00 (cloth)

\section{Paul G. Mahoney}

Published online: 9 October 2012

(C) Springer Science+Business Media New York 2012

\section{Erratum to: Public Choice \\ DOI 10.1007/s11127-012-0018-x}

The third sentence in the fourth to last paragraph is incorrect in the published article. The correct sentence is as follows:

The Supreme Court's infamous decision in Lochner v. New York (1906), striking down a New York labor statute, focused on the barrier it raised to workers earning extra money by working overtime.

The online version of the original article can be found under doi:10.1007/s11127-012-0018-x. 